\title{
Penología e indigenismo en la antigua Guinea española
}

\author{
Pedro Maria Belmonte Medina *
}

\begin{abstract}
RESUMEN
Este artículo de investigacióm pretende ser un estudio histórico-juridico del derecho penal que los españoles aplicaron a los indigenas de la Guinea española.

Partiendo de la base de que el derecho penal guineano-español se basaba, principalmente, en el reconocimiento de normas indigenas de tipo consuetudinario (derecho indígena), a través de sentencias judiciales y por adaptaciones del derecho metropolitano, usando como vehículo de expresion, asi mismo, la jurisprudencia aplicada por los tribunales de raza españoles, se hace un ámplio estudio de las penas que los españoles aplicaron a los indígenas, dividiendo la obra en dos partes: derecho para indígenas $y$ derecho indígena.

PALABRAS CLAVE

Penología, Indigenismo, Guinea, Costumbre, Colonia.

\section{ABSTRACT}

This work tries to be a historic-juridical study about penal law that spanish people applied to natives fron the spanish guinea.

From the point of view that this law was, mainly, based on the knowledge of the natives rules about habits and native law, through sentences and the adaptation of the metropolitan law, using as mass media, the jurisprudence applied by the spanish courts, a huge study, is made about the punishments spanish people applied to natives. The study is divided in two parts: native law and law for natives.

KEY WORDS

Penology, Indigenous, Guinea, Habit, Colony.
\end{abstract}

* Juez sustituto en Tarragona y doctorado en Historia del Derecho por la UNED. 
"Si ignoras dónde fue a parar tu hermano, no ignores la costumbre que llevó».

Proverbio pamúe

\section{INTRODUCCIÓN}

En virtud de los Tratados de San Idelfonso de $1^{\circ}$ de octubre de 1777, y de El Pardo de 11 de marzo de 1778 ', Portugal cedió a España las islas de Fernando Póo y Annobón, que situadas en el golfo de Guinea, poseía desde el siglo XVI, renunciando España, a cambio, a todo derecho sobre el Brasil.

España, en virtud de estos tratados va a tomar posesión de éstas tierras con la expedición del Conde de Argelejo en 1778.

Pero en realidad la soberanía de hecho sobre las islas no se produce hasta 1843 con la expedicion del comisario regio Lerena; siendo hasta entonces, incluso, posesionada y dominada por los británicos. Con el transcurrir del tiempo, estos territorios van a empezar a ser colonizados por los españoles, fundamentalmente a partir de 1858 ,fecha del primer estatuto orgánico de la Guinea española e incluso se van a ampliar las tierras bajo dominio español (islas de Corisco, Elobey chico y grande, y Guinea continental).

En 1959 los territorios españoles del golfo de Guinea se dividen en dos provincias: Fernando Póo y Río Muni (Guinea continental e islas adyacentes) y ya en 1968 conseguirían su independencia de la metrópoli; convirtiéndose en el actual Estado de Guinea ecuatorial con capitalidad en Malabo en la antigua isla de Fernado Póo.

Refiriéndonos ya al objeto de nuestro estudio, que trata acerca de las penas que aplicaron los españoles a los indígenas de aquellas tierras que delinquían, hemos de hacer las siguientes precisiones:

- Que tomamos como punto de referencia el Estatuto de justicia indígena de 1938, que es la primera reglamentación que tiene la justicia indígena.

- Necesidad de distinguir entre derecho para indigenas y derecho indígena.

- Que estando nuestro derecho penal colonial guineano prácticamente virgen en conocimientos, es un buén momento en los albores del

Vid. CoRderro TORFES: Tratado elemental del derecho colonial español. Madrid 1941, pág 30 y Miranda Junco, A: Leyes coloniales. Madrid, 1945, pp. 13-15. 
trigésimo aniversario de la independencia de la Guinea española, el aportar un pequeño estudio para conocer un aspecto concreto y desconocido de lo que un día fue "nuestra Perla de África».

\section{DERECHO PARA INDÍGENAS}

El Derecho penal para indígenas de los territorios españoles del golfo de Guinea estuvo constituido, en su mayor parte, por el reconocimento de normas indígenas de tipo consuetudinario (Derecho indígena) a través de sentencias judiciales y por adaptaciones del derecho metropolitano, usando como vehículo de expresión, asímismo, la jurisprudencia ?

El capítulo III del Estatuto de justicia indigena de 10 de noviembre de $1938^{3}$, dice al respecto que:

"los tribunales de raza dictarán sus resoluciones ateniéndose a la costumbre comúnmente admitida, siempre que no sea contraria al órden público, a los principios de la moral o a la acción civilizadora del Estado español» (art. 7).

Y en el artículo 9 se continúa diciendo:

«lo mismo en materia criminal, que en materia civil, los tribunales indigenas, sin perjuicio de la aplicación de la costumbre, procurarán, modelar y completar sus prescripciones, de suerte que lentamente se infiltre en la legislación del país, la que aplican los tribunales europeos para la sanción de hechos delictivos..."

Vemos, pués, el reflejo legal de lo expresado en los primeros párrafos de éste apartado.

En las leyes de Indias vemos un precedente claro de ésta especialidad del derecho para indígenas ${ }^{4}$, ya que junto al derecho indiano puramente territorial aparece la consagración de un sistema de normas directa y exclusivamente destinadas a indígenas, constituidas por "las leyes y buenas costumbres que antiguamente tenían los indios para su buen gobierno $y$

\footnotetext{
2 Olesa Muñido, Francisco Felipe: El derecho penal aplicable a los indigenas de los territorios españoles del golfo de Guinea. IDEA-CSIC. Madrid, 1953, p. 305

3 Este estatuto regula por primera vez la justicia indígena y fue publicado en el Boletin oficial de los territorios españoles del golfo de Guinea de 15 de enero de 1939.

4 Recopilacion de leyes de los Reynos de las Indias. Consejo de la Hispanidad, 1943, ed. facsímil de la imprenta de Madrid en 1791 de orden del Real y supremo consejo de Indias. Ley 4 , título 5, libro It.
} 
policia", mandando sean guardadas y observadas con la sola excepción de las opuestas a la religion católica y al derecho territorial recopilado.

El hecho de que las provincias de ultramar poseyesen un especial régimen jurídico es una constante en la política colonial decimonónica española, así lo expresan nuestras constituciones históricas (disposicion adicional 2. ${ }^{a}$ de la const. de 1837, art. 80 de la const. de 1845, art. 89 de la de $1876 \ldots$..

Haciendo un poco de Historia sobre el derecho penal que se aplicó a los indígenas de los territorios de la Guinea española debenos distinguir las siguientes etapas:

\section{1. $1778-1843$}

Es época en la cuál la presencia española es escasísima, por no decir nula. Para castigar a los nativos que delinquían se aplicaban las leyes de Indias ${ }^{5}$, con ello se venía a trasplantar el sistema empleado en América a las colonias africanas, y se daba una coherencia al mundo colonial hispano, que en principio, no elaboró unas normas jurídicas peculiares para las nuevas colonias.

Fue ésta, una época en la que la metrópoli española tuvo una soberanía de derecho, pero no de hecho sobre los territorios, lo cual fue aprovechado por los ingleses, que so pretexto de establecer un tribunal mixto en Fernado Póo, que acabase con el tráfico negrero se asentaron en la isla, fundando la ciudad de Clarence, posteriormente llamada SANTA ISABEL por los españoles en honor de la reina Isabel II.

Los ingleses parece ser que fueron bastante amigos de una dura justicia, sobre todo a partir de la subida al gobierno de la isla en 1829 del coronel Nicholls que implantó una justicia que dependió en exceso de la cárcel y el látigo ${ }^{6}$.

\section{2. $1843-1901$}

En esta época nos encontramos,en lo que se refiere al derecho penal, un importante hito legislativo:

5 De Castro, Mariano L. D. y DE LA Calle, M. L.: Origen de la colonización española en Guinea ecuatorial. Universidad de Valladolid, 1989 , p. 35.

6 De Castro-De la Calle. Op. cit., p. 110. 
- CÓDIGO DE LERENA. Es el primer texto codificado de la colonia, con importantes normas relativas a derecho penal.

Es fruto del Consejo constituido en Clarence como consecuencia de lo previsto por el comisario regio D. Juan José de Lerena y Barry, quien inicia nuestra acción colonial en la zona con la presencia de la expedición mandada por él y que a su vez se presenta como comisionado con plenos poderes para ejercitar los derechos de soberanía que España poseía desde 1777-1778.

Es el Código de Lerena un típico ejemplo de código local o de leyes privadas, o mejor privativas, pero la inexistencia de los delitos fundamentales o básicos, aquí no incriminados, implica la validez y subsistencia del código penal metropolitamo español.

Finalmente,respecto a los indígenas, hay que decir que éstos aparecen ya en el texto:

A) Innominados en la descripcion de algún tipo como el de "destrucción de la propiedad de una manera insolente " ${ }^{7}$,en referencia expresa a la que pertenece a los habitantes de la ciudad o nucleo colonizador, o a otra gente, en referencia al nativo.

B) Como sujeto pasivo de un particular delito, a saber: "el de comercio injusto e injuria contra los naturales de la isla ${ }^{8}$ que va a sancionar el uso fraudulento en el comercio o permuta, el apoderamiento sin permiso de pesca,vino de palma u otros artículos, el golpear o herir a alguno en comercio o en los bosques, y los hechos contra la honestidad cometidos con mujeres indígenas. Se sancionan a beneplácito del Gobernador y el Consejo.

\section{3. $1902-1938$}

La RO de 23 de julio de $1902{ }^{9}$ es de gran importancia,ya que dispone la aplicación del Codigo penal español de 1870 a los individuos de origen europeo e indígenas convertidos al cristianismo.

La extensión a las colonias guineanas del texto de 1870 se pudo hacer en base al art. 87 de la Constitución entonces vigente (1876) que autorizaba a extender a las colonias, con las modificaciones convenientes y dando cuenta a las Cortes, las leyes promulgadas o que se promulgasen

Código de Lerena, cap. IV, art. $6^{\circ}$

Código de Lerena, cap. $V$, art. $7^{\circ}$.

Miranda Junco, A: Leyes coloniales. Madrid, 1945, referencia 223. 
para la península, a pesar de hallarse las llamadas "provincias de ultramar» bajo régimen de legislación especial ${ }^{10}$.

Esta RO no dispone nada respecto a los indígenas no convertidos al cristianismo, pero al prever el apartado 10 de la RO de 1902 que cuando se presentase alguna cuestión sobre la que no se hubiere legislado, y siendo la del derecho aplicable,caso de delinquir un indígena no cristiano una de ellas, debe ser resuelta por el juez con arreglo a la costumbre del lugar, a los principios generales del derecho y a la equidad; en este apartado reside la base del ordenamiento penal para indígenas guineanos hasta la promulgación del Estatuto de justicia indígena de 1938.

La RO de 23 de mayo de $1930{ }^{11}$ nos dice que han de entenderse por convertidos los indígenas que profesen el cristianismo, cualquiera que sea su religión, dentro de éste; fórmula que abarca con los católicos, los adectos a todas las sectas protestantes.

Hay que notar que la distinción entre indigena no converso e indígena converso y europeo recae sobre la norma aplicable, pero no respecto al órgano encargado de adiministrar justicia, que es el mismo, osea: si el hecho es constitutivo de delito (Juzgado de Santa Isabel en trámite de sumario y Audiencia de Las Palmas en trámite de juicio oral).

\section{De 1938 en adelante}

Por el Decreto de 10 de noviembre de 1938, publicado en el Boletín oficial de las colonias de 15 de enero de 1939 la justicia indígena va a tener una primera regulación específica.

Este Estatuto va a ser el punto central alrededor del cual va a girar este breve estudio, centrado igual que el Estatuto en los indígenas no emancipados.

\section{Noción legal de indígena en derecho penal guineano}

\subsection{Indígena no emancipado}

Es el centro de estudio y aquel al que va dirigido la normativa incluida en el EJI ${ }^{12}$, por eso interesa fijar qué se entiende legalmente por indígena no emancipado.

10 Miranda: Op. cit., ref. 727.

MiRANDA Junco, A.: Op. cit., ref. 1133.

EJI: Estatuto de justicia indigena de 1938. 
$Y$ al respecto ${ }^{13}$ debemos decir que gozaban del status de indígena no emancipado en derecho penal colonial guineano español:

A) "LOS INDIVIDUOS DE COLOR», incluso mestizos no reconocidos por el progenitor blanco que fuesen patrocinados y que por lo tanto carecieran de carta de emancipacion plena y de título profesional o académico expedido por centro oficial español, aunque fuesen hijos o cónyuge de emancipados o gozaren de emancipación limitada.

B) "LOS INDIVIDUOS DE COLOR" incluso mestizos no reconocidos por el progenitor blanco perteneciente a los grupos étnicos del África ecuatorial, sin plena capacidad jurídica según su propio estatuto personal, que estuviesen avencidadas en los territorios españoles del golfo de Guinea o residiesen en ellos por razon de un contrato de trabajo o por poseer bienes inmuebles.

Se van a exceptuar del grupo a) y tienen, por tanto, consideracion legal de emancipados, los que con anterioridad a la entrada en vigor de la ley de 1949 de 21 de abril, les haya correspondido de pleno derecho la emancipacion por hallarse empleados durante dos años en un establecimiento agrícola o industrial con sueldo igual o superior a cinco mil pesetas anuales, o por ser auxiliar indígena mayor o asimilado al servicio del Estado o de un Consejo de vecinos o por ser esposa legítima o hijos en potestad de emancipado.

\subsection{Mestizo}

El mestizo, que es el hijo de progenitores de distinto color, estuvo en el derecho colonial guineano español, hasta el decreto de 7 de marzo de 1952, sin una regulación específica.

Dado que el mestizaje hasta 1952 carecía de estatuto jurídico propio, lo que se hizo fue equipararle al no emancipado si su círculo cultural era el nativo, sin que tal posición fuese, para el legislador de la época, lesión de derecho, sino "simple reconocimiento de facto de la incapacidad del mestizo en éste caso de adaptarse a otras formas culturales más perfectas " ${ }^{14}$.

El decreto de 7 de marzo de $1952{ }^{15}$ considera individuos de color a los mestizos no reconocidos por el progenitor blanco.

\footnotetext{
OLESA MUÑIDO: Op. cit., p. 127.

OLESA, p. 125.

Aprueba el nuevo estatuto del patronato de indígenas de los territorios españoles del Golfo de Guinea.
} 
La noción legal de «individuo de color» dada en el propio decreto comprende a "todos aquellos que no sean hijos de blancos, y los que siéndolo de padre o madre no hayan sido reconocidos legalmente por ellos" y es la condición que posibilita el concepto indígena.

El mestizo reconocido por el progenitor blanco queda, al no ser individuo de color, excluido del indigenato.

\subsection{Indígena patrocinado}

El indígena patrocinado (por el Patronato de indígenas) es sujeto de color y no emancipado, cuyo concepto legal abarca no sólo a los pertenecientes a las tribus aborígenes de nuestros ex-territorios, nacidos dentro o fuera de ellos, mientras no hayan perdido la nacionalidad española con arreglo al Código civil,sino tambien a los que sin pertenecer a las tribus aborígenes de las colonias nazcan en ésta cuando con arreglo al $\mathrm{Cc}$, opten por la nacionalidad española o adquieran esta por vecindad con arreglo a la ley y a los que no acrediten una nacionalidad determinada en tanto residan en la colonia o tengan en ella sus nedios de vida. Mientras no adquieran una nacionalidad distinta, las esposas e hijos de los individuos de color patrocinados seguiran la condicion jurídica del cabeza de familia.

\subsection{Individuos de color no emancipados ni patrocinados}

A éstos se les sometió, en virtud del art. 6 del Decreto de 7 de marzo del 52, mientras permaneciesen en el territorio colonial a las normas de seguridad, policía y buen gobierno que estaban en vigor en el mismo, disfrutando solamente de los beneficios que en este aspecto se concedía a los emancipados españoles, cuando el Gobernador general, mediante justa causa, así lo declarase de modo expreso y concreto.

\subsection{Indígenas emancipados}

Según el art. 6 del EJI tendrán la condición legal de indígenas emancipados y por tanto no sujetos a su regulación:

a) Los que, conforme a las disposiciones vigentes hayan obtenido carta de emancipacion. 
b) Los que posean título profesional o académico, expedido por la Universidad, instituto u otro centro oficial español

c) Los que se hallen empleados durante dos años en un establecimiento agrícola o industrial, con sueldo igual o superior a 5.000 ptas. anuales.

d) Los que estén al servicio del Estado o de los Consejos de vecinos, con una categoría igual o equivalente a la de auxiliar indígena mayor 0 asimilada.

Termina diciendo el art. 6 que la esposa e hijos del que obtenga carta de emancipación o le corresponda, de pleno derecho, gozará de la capacidad que las leyes españolas les otorgan en relacion con el jefe de familia.

Este último párrafo fue derogado implícitamente y sustituido por la ley 21 de abril de 1949, ya que el art. 6 in fine del estatuto cometía la omisión de no especificar si la mujer e hijos del que obtenía carta de emancipación debían serlo a su vez ${ }^{16}$.

Pues bien, el art. $2^{\circ}$ de la ley de 1949 dice que al emancipado le corresponde el ejercicio sobre su esposa e hijos no emancipados de los derechos y deberes propios de la autoridad marital.

\section{Necesidad de una legislación privativamente aplicable a indigenas}

La duplicidad de culturas, con recíproca influencia, que coexisten en un mismo ámbito colonial, exige una duplicidad legislativa.

No resulta factible proceder a la aplicación del mismo régimen jurídico a hombres de diferentes culturas. Es preciso, pues, especializar la ley.

Nada más erróneo que la idea de que nuestra ley más perfecta puede ser indistintamente aplicada al medio indígena, y aún ser siempre beneficiosa para éste. Las leyes hechas para la metrópoli son casi siempre impropias para África.

"La forzosa aplicación - dice Olesa- al ámbito nativo de la ley de la metrópoli, que maneja conceptos, regula instituciones y actúa mediante órganos que no son los que el indígena vive,provoca el apartamiento de éste de nuestro sistema penal, ya recurriendo por el hecho cometido, a sus órganos naturales, que continuarán así con una práctica autoridad y

16 Olesa: Op. cit., p. 124. 
jurisdicción aunque indivisible, existente, al margen de la acción colonial, ya colocándose el penado ante un sistema de ejecución extraño a su mentalidad, en una posición abstencionista, ausente, que inhabilita para que la pena pueda cumplir la función correctora asignada, deviniendo así, en su acción sobre el penado, inhumana o inutil ${ }^{17}$.

Así, por ejemplo, la prisión no es para que intimide o morigere al indígena. Su inercia le resigna con facilidad a la privación de libertad, sobre todo, compensada con un mayor bienestar, ya que siempre la peor de las cárceles es más abrigada que la choza y el rancho más apetitoso y variado que la comida indígena" ${ }^{18}$.

Es necesaria la ley para el indígena y ésta ha de ser especial.

No se debe pensar que este especial derecho atente contra el principio de igualdad ante la ley, ya que igualdad en el régimen jurídico presupone igualdad en los supuestos sociales del mismo.

La ley especial para indígenas no es conculcación de un derecho, sino explícito reconocimiento del que tiene el nativo a su propia tutela jurídica y a la de sus fundamentales valores culturales.

Así, pues, la especialización de la ley ante el medio colonial, que influye y condiciona, no es un capricho sino una necesidad vital.

\section{Estructura del ordenamiento penal guineano para indígenas}

El EJI fija un doble principio:

A) Reconocimiento como norma primaria del derecho indígena a la costumbre, condicionado a su no oposición al órden público, a los principios de la moral o a la acción civilizadora del Estado.

B) Existencia de una adaptación de la norma metropolitana orientada a modelar la costumbre indígena y ser suplente con la idea expresa de introducirse progresivamente en la legislación del país.

Las tribus de nuestra Guinea (bubis y pamúes) carecían de cuerpos legales, tan solo el emperador de Riabba -MOKA- ${ }^{19}$, publicó, a causa probablemente de su contacto con las formas jurídicas europeas, una especie de Código penal resumido. En su virtud, era castigado el ladrón, el

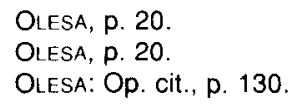


que atacare a un viajero pacífico; el que matare con violencia o engaño sin guerra declarada era a su vez muerto, etc.

La costumbre, es pues, la fuente de derecho indígena por excelencia ${ }^{20}$, respecto de la cual la posición del indígena es conformista, no por pasividad sino por identificacion con ella, ya que opina que las costumbres no deben ser tan malas cuando las mismas autoridades coloniales las toleran y defienden.

Aquellas bastaban para su elemental subsistencia. A nuestro respecto y en virtud del art. 7 del EJI, la única forma de derecho indigena vigente es la costumbre, ya que de acuerdo con el decreto del gobierno general de 28 de mayo de 1907 los jefes de poblado o tribu carecen de capacidad para crear normas de contenido penal e incluso de la jurisdicción necesaria para imponer castigos por los delitos cometidos, reservada especialmente a los órganos coloniales. Sobre el tema destacamos las siguientes palabras de Olesa Muñido:

"La costumbre aparece en el ámbito guineano, unas veces como hábito en las relaciones entre hombres, que permite inducir que éstos obran creyendo cumplir un deber necesario para la conservación del orden establecido. En otros casos, la tradición de grupo o leyenda recogen la norma consuetudinaria bajo la forma de relato vivido o de apólogo que destaca la sanción recaída por obra humana o sobrehumana (norma sancionadora) contra el infractor de la conducta ordenada. El refranero es también un importante vehículo para el conocimiento de la costumbre en su forma más condensada expresión generalmente de los principios básicos del derecho indigena" ${ }^{21}$.

La costumbre como fuente de derecho, esencialmente viva, tiene como consecuencia su mutabilidad y en lo procesal su necesidad de prueba. Por ello, el art. 7 del EJl exige que la costumbre, a la que los tribunales de raza deben atenerse con las excepciones que a contiuacion se verán, para dictar sus resoluciones sea comúnmente admitida.

El hecho de que no se haya usado la expresión "costumbre del lugar", tradicional en nuestras leyes y sí la de "costumbre comúnmente admitida", piensa el profesor Olesa, que es debido al criterio del legislador dirigido a no darle un contenido territorial, sino étnico.

La exigencia de que sea comúnmente admitida suscita una serie de problemas, ya que o significaba que es necesario, para su validez como

20 Un proverbio pamúe reza: «si ignoras dónde fue a parar tu hermano, no olvides la costumbre que llevó".

21 Olesa: Op. cit., p. 132. 
norma de derecho aplicable, su extensión a todo el ámbito externo,y territorio guineano, e interno, círculo cultural, o supone, en lo penal, que sea la costumbre común, aún en lo incriminativo, a delicuente y medio indíigena en que delinque.

Esta última postura aclara bastante el problema de la norma aplicable en los frecuentes casos de hechos delictivos cometidos por indígenas del África ecuatorial no española, pero la subjetivación del derecho que ocasionaría tendría como consecuencia, la imposibilidad de castigar hechos, que, aunque solo fuere por razones de política criminal, no puedan ser mantenidos en la impunidad.

El carácter de la costumbre plantea el problema de si ha de ser alegada y probada en el proceso por la parte o si, por contra, incumbe a los Tribunales de raza ${ }^{22}$.

Pues bien, en base al art. 7 del EJl y de la noción de costumbre comúnmente admitida, junto con el art. 22 b) se puede inducir que la comprobación debe hacerse ante el tribunal y por éste, pero la alegación podrá realizarla, y la proposicion de los medios de prueba, el imputado.

La costumbre no debe ser aplicada por los Tribunales de raza de nuestros territorios del golfo de Guinea como derecho indígena, sino convenientemente integrada como derecho para indígenas, cumpliendo una función de acción colonial y siempre y cuando no sea contraria:

\section{- Al orden público}

El concepto de órden público surge entonces, no como conflicto entre leyes de distinto Estado, sino entre principios y normas legales de distintas culturas reconocidas por el ordenamiento colonial de un solo Estado que al generar el proceso colonial, parte necesariamente de la creencia y aceptación de la superioridad de la cultura propia, ya que en caso contrario sería, no sujeto activo, sino pasivo de colonización, esto es, colonizado.

La noción impeditiva de órden público no se produce con la no coincidencia entre el ordenamiento y las normas de otros reconocidas por el primero o por otro de jerarquía legal superior, sino que exige que "sean contrarias a las que expresan ciertas concepciones fundamentales consideradas básicas en materia de organización y disciplina de la vida so-

22 Así son llamados por el EJl, ya que por tener constitución mixta, se componen de un número de elementos nativos que ilustran sobre la norma privativa e indigena. 
cial» ${ }^{23}$. Como, por ejemplo, los que imponen el respeto hacia la personalidad y dignidad humana.

\section{- A los principios de la moral}

Son los principios de derecho natural que todo hombre lleva en si por esencia ética, y por lo tanto, el conflicto no es de culturas, sino del grupo formulador de la norma consuetudinaria consigo mismo por abandono y olvido de aquéllos.

\section{- A la acción civilizadora del Estado}

Esta excepción, implícita ya en la de orden público, nace y es el culmen de todo proceso colonial rectamente concebido. Esta acción civilizadora es el natural límite a la validez de las normas de derecho indígena y el medio de imponer su progreso y hacer respetar la labor colonizadora.

Para acabar este epigrafe diremos que la excepción de orden público, en sentido técnico y subsumiendo las otras dos, tiene en lo jurídico la siguiente función:

a) Suprime instituciones indígenas.

b) Fundamenta la aplicacion de normas metropolitanas.

c) Motiva el dictar normas especiales para el ámbito colonial.

\section{Función colonial del derecho metropolitano}

El art. 9 del EJI ${ }^{24}$ fija las condiciones en que el adaptacionismo debe producirse; función del derecho colonial de la metrópolis.

No se trata de una extensión de normas penales metropolitanas de pleno derecho, sino de una infiltración que module y complete las prescripciones de la costumbre, lo que exigirá que la legislación metropolitana se adapte a las condiciones jurídicas del país guineano.

23 Olesa: Op. cit., p. 136.

24 Lo mismo en materia criminal que en materia civil, los Tribunales indigenas, sin perjuicio de la aplicación de la costumbre, procurarám modelar y completar sus prescripciones, de suerte que lentamente se infiltre en la legislación del país la que aplican los tribunales europeos para la sanción de los hechos delictivos o para la resolución, en vía contenciosa, de los conflictos que resuelva el derecho privado. 
Por ello, el Tribunal superior de justicia indígena, aunque sienta jurisprudencia, en sus decisiones, ésta es vinculante para los jueces inferiores, según dispone el art. 19 del Estatuto, pero no para sí, reservándose la adaptacion actualizada del derecho a la situación evolutiva del cuerpo indígena.

Cuando la costumbre nativa no sea aplicable por su incompatibilidad con nuestro ordenamiento, la modelación adquiere caracteres de introducción de la norma subsidiaria que sustituye, completando el ordenamiento, la consuetudinaria rechazada.

En el campo penal, que es el que nos ocupa, la disparidad entre costumbre indigena y principios básicos de nuestro ordenamiento se puede dar en los elementos de incriminación o en el aspecto punitivo.

En el primer supuesto, unas veces el derecho indígena considerará delito ${ }^{25}$, actos no reprochables desde el punto de vista de nuestro ordenamiento, lo que impedirá aceptar el derecho nativo como norma de resolucion, en otros la costumbre comúnmente admitida aprueba actos que repugnan al orden público o a la moral, como el homicidio del hechicero, y es preciso aplicar nuestro derecho más cuidadoso en la tutela de la vida como bien jurídico supremo.

La introducción en el ámbito de la Guinea de instituciones de derecho penal metropolitano es obra de la coexistencia de una norma primaria indígena (costumbre comúnmente admitida) y limitada por las tres excepciones vistas, y la norma informadora metropolitana que no solo completa, sino que sustituye a aquélla cuando por no concurrir los supuestos del art. 7 del EJl carece del carácter de norma aplicable.

Por ello, y en relación a los indígenas no emancipados, el código penal metropolitano no rige en los territorios españoles del golfo de Guinea como cuerpo de leyes, sino como formulación positiva de las normas cuya transgresión tiene sanción penal, destacándose como sistema de expresión de un orden jurídico, no como catálogo de delitos y penas trasplantado a un ámbito colonial determinado.

Es el sentir jurídico del grupo indígena (costumbre) modelado por el ordenamiento de la metrópolis como integración orgánica de las normas expresadas como anticonducta en nuestra ley penal, la verdadera sustancia, según los textos vigentes, del ordenamiento jurídico penal guineano para indígenas.

25 Hechiceria involuntaria. 
Por ello pueden y deben ser admitidas en él figuras de delitos específicamente coloniales y por tanto no incluidos en el articulado del código y leyes especiales metropolitanas, pero sí con estructura penal básica en la costumbre, aunque en algún caso impunes en ella por concurrir pretendidas justificaciones.

El homicidio antropofágico, por ejemplo, no debe ser castigado como un homicidio o un asesinato de estructura común a la del establecido en el ordenamiento metropolitano, sino como homicidio antropofágico, con base incriminativa en la propia costumbre.

Es muy interesante, al respecto, la sentencia del Tribunal superior de justicia indígena de 24 de octubre de 1947 publicada en el BOC ${ }^{26}$ de 15 de abril de $1949^{27}$.

En nuestro ordenamiento la costumbre indigena tiene validez en tanto es reconocida por un precepto legal de España, el decreto de 10 de noviembre de 1938 del EJl.

Rige por reenvío, deduciéndose que la costumbre se incorpora como derecho positivo español dimanante de lo dispuesto en una disposición legal, y es lógica consecuencia la admisión de que la declaración explícita de una voluntad de acción colonial tiene prioridad sobre la implícita del reconocimiento de un status jurídico, cuya restricción resulta del propio acto de reconocimiento.

La ley para indígenas es un medio de infiltrar el derecho metropolitano concorde con el art. 9 del EJI, dictado no ya por el tribunal en quien delega el legislador la facultad de adaptación, sino por este mismo.

Por último vamos a referinos al ámbito territorial de aplicación de la jurisdicción para indígenas y hemos de citar el art. 1 del EJl.

En concreto, el ámbito territorial es: «isla de Fernando Póo y la Guinea continental que a su vez incluye además los islotes de Annobón, Corisco y Elobey grande y chico".

Respecto a la incompatibilidad entre el sistema de penas consuetudinario, nuestro legislador quiso en el art. 8 del EJl prohibir la penalidad indígena, que en general, fuese manifiestamente inhumana o contraria al espiritu en que se inspiran los ordenamientos penales españoles, citando con valor de ejemplo las penas del talión y las mutilativas.

\footnotetext{
$\mathrm{BOC}=$ Boletín Oficial de los Territorios españoles del Golfo de Guinea.

27 El BOC se empezó a publicar desde 1909 cada 15 días. En la actualidad se puede consultar en la Biblioteca Nacional.
} 
Estando basado fundamentalmente el sistema punitivo en la aplicación de penas corporales, nuestro ordenamiento, al prohibir éstas exige su sustitución y correlativamente impone para tal caso la sanción en base a la legislación metropolitana (salvo normas especialmente aplicables) que fija la naturaleza de las penas susceptibles de ser impuestas.

\section{Las penas}

\subsection{En la legislación de Indias}

Hasta 1843 a los indígenas de nuestra Guinea se les aplicó la legislación de Indias, que en lo referente a penas se contenía en la ley 10 , título VIII, del libro VII de la Recopilacion de leyes de Indias.

Según ésta, no existen para los indios, galeras, fronteras ni destierros a Castilla. Los indios no suelen reputar como penas los azotes; las pecuniarias les son excesivamente gravosas; la servidumbre personal no perpetua y proporcionada en el tiempo al delito cometido es eminentemente correctiva, ya que pone al penado en situación de ganar algún dinero y aprender oficio; el servicio ha de ser a conventos u otros ministerios.

El destierro, salvo casos graves, no puede exceder de la ciudad cabeza de provincia a que pertenece el pueblo.

\subsection{El Código de Lerena de 1843}

Las penas son indiferenciadas, por eso nos remitimos a lo dicho en páginas anteriores ${ }^{28}$.

\subsection{La pena de muerte}

Las razones que llevan a que un ordenamiento aplique la pena de muerte no cambian entre metrópolis y colonia.

En derecho consuetudinario nativo era muy frecuente la pena de muerte, por ello el indígena siente la condena a muerte, como una pena y le otorga un profundo significado de reproche social, saturando su ejecución de contenido expiatorio. 
Las razones que se pueden aducir en favor de una menor responsabilidad del indígena, por el hecho de serlo, parecen poco jurídicas, poco humanas.

El indígena puede ser malvado y lo es en ciertos casos, puede querer producir el mal voluntaria y conscientemente, como puede hacerlo un europeo y en consecuencia la jurisprudencia del Tribunal superior de justicia indigena de nuestros territorios ha repetidamente impuesto y ha sido ejecutada la pena de muerte por ahorcamiento, asimismo se impuso la pena capital en razón a los asesinatos cometidos por la secta «MBUETI».

El robo con homicidio, premeditado y alevoso del compañero de trabajo enfermo ${ }^{29}$, y el asesinato cualificado por la alevosia con las agravantes de premeditación, nocturnidad y ofensa al respeto debido al cargo son merecedoras de pena capital tanto en derecho consuetudinario como en la jurisprudencia del TSJI ${ }^{30}$.

Es curioso pero la pena de muerte no se consideraba inhumana; no olvidemos que el EJI prohibía aplicar penas inhumanas a los nativos.

\subsection{Las penas privativas y restrictivas de libertad, la multa}

La pena de cárcel no es pena que por sí intimide o mejore al indígena. Más que una pena, la cárcel es una recompensa para el nativo.

Al indígena, para sentir que la cárcel es una pena le falta tradición consuetudinaria y contenido expiatorio, que sí posee, por contra, la imposicion de un trabajo ${ }^{31}$.

Reclusiones, prisiones, presidios, y arrestos son, pues, poco eficaces para sancionar al indígena, más aún en un territorio que carece de estructura institucional penitenciaria.

Las distintas penas privativas de libertad quedaron, en realidad, reducidas en nuestra ex-colonia a una sola: la pena de cárcel; y esto debido a la reducida extensión de nuestros territorios y su especial estructura, que hubiera obligado a una duplicidad de establecimientos en continente e isla, por exigencia geográfica que impidió la complejidad institucional de dar contenido penitenciario propio a las distintas penas privativas de libertad.

29 Sentencia de 25 de abril de 1947, publicada en BOC de 15 de julio de 1947.

ST de 26 de nov. de 1948.

31 Entre la tribu "nuer", la casa del hechicero servía de cárcel, en la que solo permanecía hasta que era juzgado. 
En nuestra Guinea la pena privativa de libertad fue acompañada del "trabajo»; esto hizo que la cárcel no fuera algo inútil para los intereses de España y más en un lugar falto de mano de obra.

La tradición consuetudinaria de que carece la reclusión como pena ${ }^{32}$ en el medio indígena, la posee la obligación de trabajo a favor de la comunidad o del agraviado que hallamos aplicada entre los bubis de Fernando Póo:

"El trabajo, da asi, al indígena el contenido expiatorio y ritual que la reintegración del orden postula, debiéndose unir a ello la reclusión en el establecimento penitenciario para cumplir los restantes fines y destacar el factor diferencial existente entre el trabajo como función social y la obligación penal de trabajar» ${ }^{33}$.

La jurisprudencia de nuestro TSJI declaró el íntegro abono de la prisión preventiva a los efectos del cumplimiento de la pena que fuese impuesta.

Respecto a la multa, hay que hacer constar que ésta tuvo para el indígena verdadero significado de pena y no solo de reparación.

Si vamos a la casuística, nos encontramos con ejemplos de tales penas en sentencias de nuestro TSJl, tales como:

- 6 de diciembre de 1946 y 23 de febrero de 1948 (por delito de falsedad en documento público cometido por funcionario indígena se sanciona con 1 a 2 años de presidio menor y multa de 1.000 ptas.).

Para la falsedad de documento privado las penas impuestas en las sentencias analizadas oscilan entre 8 meses de arresto mayor a 2 años y 6 meses de presidio menor (sts. de 29 de agosto de 1947 y 10 de octubre de 1947 y 29 de octubre de 1947).

El uso público indebido de nombre supuesto es penado con 6 meses de arresto mayor y multa de 1.000 ptas.

Por delito de quebrantamiento de condena se ha penado con 4 meses de arresto mayor (sts. de 25 de enero de 1947, 28 de febrero de 1947, 14 de marzo de 1947 y 17 de diciembre de 1947, publicadas en BOC de 15 de mayo de 1947, 1 de noviembre de 1947, 1 de nov. de 1947 y 1 de junio de 1950).

Por violación se aplicaba prisión mayor (menor que en derecho metropolitano) (st. de 21 de febrero de 1947 publicada el 1 de nov de 1947).

32 Tan solo en algunas ocasiones se privaba de la libertad de locomoción maniatando o atando a un poste al acusado y más raras veces al penado.

33 Olesa, op. cit., p. 285. 
La prueba clara es que se aplicaba en casos en que por no existir daño material ni perjuicio materialmente evaluable, la multa reintegraba, en derecho consuetudinario, solo un valor espiritual como en el desacato y la calumnia.

Nuestra jurisprudencia para indígenas admitió la multa, como asimismo el arresto subsidiario en defecto de su pago, modelándolos en el sistema penal metropolitano.

\subsection{Inaplicabilidad en nuestra colonia de las penas corporales}

Se hallaron expresamente excluidas de nuestros territorios en el Golfo de Guinea esta clase de penas por ser «manifiestamente inhumanas y contrarias al espíritu en que se inspiran las ordenaciones penales españolas".

Estas penas históricamente conocidas en nuestro país (azotes, mutilaciones...) no están recogidas en los códigos penales del siglo xx y no se aplicaban en derecho penal para indigenas de la Guinea. La oposición e ellas resulta de textos legales, exposiciones de motivos y comentaristas.

Otra cosa es que en la práctica los hacendados practicasen los malos tratos sobre los nativos trabajadores en sus plantaciones $y$ esto de hecho ocurrió; prueba palmaria es la rebelión que en 1910, LUBA, jefe del poblado bubi de Balaché, encabezó - al estilo de Espartaco en la Roma del siglo I A.C. - una revuelta contra la prestación personal y los malos tratos y la muerte de 40 bubis trabajadores que solo pudo ser sofocada tras la destrucción del poblado por el ejército español ${ }^{34}$.

La Dirección general de Marruecos y colonias no ignorando esta realidad de los malos tratos a los indígenas, lo puso de manifiesto en la RO de 15 de junio de 1929.

Se puede decir que en el tema de penas corporales para indígenas, España estuvo más evolucionada que otros países como Inglaterra que sí aplicaron a los indígenas de sus colonias esta clase de castigos.

34 Pereira Rodriguez, Teresa: «El tactor trabajo en la explotación española de los territorios del golfo de Guinea", en la obra colectiva Las relaciones exteriores de España en la edad contemporánea. Univ. de Murcia, 1989. 


\subsection{Aplicación de la pena}

En esta cuestión fue preciso que los tribunales tuviesen un amplio margen de discreccionalidad que permitiese adecuar la pena al cúmulo particular de circunstancias y motivaciones concurrentes en cada hecho, con independencia inclusive de las circunstancias modificativas de responsabilidad, posible en nuestros territorios de la Guinea gracias a la vigencia de la costumbre y a la facultad de adaptación reconocida y confiada en el EJI a las propias jurisdicciones especiales para indígenas.

Es de hacer notar también que las penas aplicadas a los indígenas son frecuentemente inferiores a las que corresponderían de conformidad con lo establecido en el código penal metropolitano.

También hay que hacer notar que la remisión condicional de la pena durante un plazo, siempre que durante éste el reo observe buena conducta, fue institución ampliamente aplicada en ámbitos coloniales ${ }^{35}$.

\subsection{La responsabilidad civil y sus relaciones con la extinción de la responsabilidad penal}

La extinción de la responsabilidad penal por fallecimiento del imputado es consecuencia del principio de personalidad de las penas. Así lo declara la sentencia del TSJl de 31 de octubre de 1947 publicada el 11 de mayo de 1949 en BOC.

Sin embargo, la extinción de la responsabilidad penal no supone la exoneración de responsabilidad civil para con el patrimonio del procesado difunto como erróneamente pudiera inducirse del fallo de la sentencia citada al condenar a la devolución del valor de lo sustraído tan solo al supérstite, fallo motivado porque la responsabilidad civil que muerto el imputado debe declararse contra él, tan solo puede serlo en procedimiento civil y no en penal.

\section{DERECHO INDÍGENA}

La costumbre, como ya hemos dicho, era la fuente de derecho indígena por excelencia.

35 Ver entre otras sts. la del TSJI de 28 de mayo de 1947 publicada en el BOC el 1 de noviembre de 1947. 
"La costumbre aparece en el ámbito guineano unas veces como hábito en las relaciones entre hombres, que permite inducir que éstos obran creyendo cumplir un deber necesario para la conservación del orden establecido. En otros casos la tradición de grupo o la leyenda recogen la norma consuetudinaria bajo la forma de relato vivido o de apólogo que destaca la sanción recaída por obra humana o sobrehumana (norma sancionadora) contra el infractor de la conducta ordenada. El refranero es también un inportante vehículo para el conocimiento de la costumbre en su forma más condensada, expresión generalmente de los principios básicos del derecho indígena” ${ }^{36}$.

Nosotros vamos a ver aquí los sistemas penológicos en derecho bubi ${ }^{37}$ y pamúe ${ }^{38}$.

\section{Las penas en derecho consuetudinario bubi ${ }^{39}$}

En derecho bubi la pena de muerte castigaba la sedición o rebelión contra el "BOTUKU» ${ }^{40}$, la cual se ejecutaba seguidamente de ser habidos los culpables en la plaza del pueblo y ante toda la población reunida, decapitándose a los reos por el verdugo oficial. También el homicidio voluntario se castigaba con la pena capital.

En épocas antiguas existió la bárbara costumbre de atar a la espalda del homicida, el cadáver del muerto, sujetando los brazos de aquel para que no pudiera soltarse y de esta guisa se le abandonaba en el bosque prohibiendo que se le prestara todo tipo de ayuda, hasta que finalmente moría al poco tiempo.

El envenenamiento era sancionado entre los bubis con la muerte si habia sido consumado; si solo se habia producido en fase de tentación, aunque la víctima quedase enferma, únicamente debía pagar en concepto de pena 5 o más cabras al jefe.

La tendencia de los jefes nativos fue la extensión de la condena a muerte en todo homicidio que postulase una reacción colectiva. El adulterio no consentido se castigaba también con pena de muerte en derecho bubi, aunque sólo en casos extremos, y el homicidio antropofágico.

\footnotetext{
36 Olesa, op. cit., p. 132.

Los Bubis eran los nativos de Fernando Póo.

Los pamúes eran los nativos de la Guinea continental.

39 Crespo Gil-Delgado, Carlos: Notas para un estudio antropológico del bubi de Fernando Póo. Instituto de Estudios Africanos (IDEA). Madrid, 1949.

40 El Botuku era el juez supremo que no admitia apelación en sus decisiones.
} 
Las penas privativas de libertad no se usaron, apenas, entre los indígenas, como ya hemos visto. La falta de tradición consuetudinaria de esta pena se sustituyó por el trabajo forzado, que, a su vez, era de carácter alternativo. Así, se sancionaban con esta pena, los delitos contra la religión, tales como irreverencia o falta de observancia de los ritos, para el caso de que el reo fuera pobre y no pudiese pagar la pena principal que era multa de cabras.

Los trabajos forzados son en beneficio del "Bojianmó» ${ }^{41}$ del poblado y durante mucho tiempo; si el culpable, por su edad, o condiciones físicas no podía dedicarse a trabajar era expulsado del poblado sin ninguna contemplación. La calumnia y falsos testimonios se penaban con multa de cabras o trabajos forzados en beneficio del calumniado. La desobediencia o desacato a las autoridades se castigaban con multa o trabajos forzados en beneficio del pueblo.

Entre los bubis era frecuente la pena de expulsión del poblado, así, por ejemplo, las faltas de respeto o desobediencia a los padres se castigaba con la expulsión, no solamente de la familia, sino también del poblado, pasándose aviso a los poblados vecinos, a fin de que el penado no recibiera ningún auxilio. En estas condiciones y acosado por el hambre no tenía más remedio que regresar a su domicilio y solicitar humildemente el perdón con muestras de arrepentimiento; perdón, que se le concedía mediante algunos castigos.

A los reincidentes en el desacato a la autoridad se les expulsaba al bosque sin recursos algunos, lo cual equivalía a la muerte por hambre.

También se aplicó la pena de multa (en cabras generalmente o en piedrecitas "chibo", que era su instrumento monetario) en delitos tales como los que atentaban contra la religión, el desacato a la autoridad, la calumnia $y$ el falso testimonio y el robo (que se multaba con el doble del valor de lo robado por la víctima).

Otras penas aplicadas fueron la infamia pública para la cual el condenado no podía participar durante un año en ninguna fiesta o ceremonia del poblado ni ser invitado a ninguna casa para fiestas o banquetes. Se solía aplicar al ladrón como pena accesoria.

También se aplicó la pena del talión (hasta que la energía de la actuación del emperador Moka acabó con esta perniciosa costumbre) y penas

41 Era el hechicero principal del poblado. 
tan anecdóticas como la que se aplicó al ladrón en tiempos antiguos de no servirse de sus manos para beber o comer durante un año, debiendo ser atendido por su familia.

Vamos a ver, por último, el delito de adulterio, cómo se castigó de diversas formas según la época y según la zona. Era el adulterio uno de los delitos que los bubis valoraban como más grave y que en consecuencia castigaban de manera más severa. El hecho de que los castigos variasen según época y lugar ha hecho que los autores no se pusiesen de acuerdo en cómo se castigaba a los adúlteros.

Según unos (Usera) ${ }^{42}$ antes de la llegada española, a la mujer adúltera se le castigaba cortándole la mano derecha y según otros (Sorela) ${ }^{43}$ abrasándoles la mano izquierda, sumergiéndola en aceite hirviendo hasta que se desprendiera la carne.

Según el padre Aymení ${ }^{44}$ en las comarcas del norte de la isla, una vez que se averiguaba el adulterio se castigaba al hombre culpable con una multa igual al duplo de la dote pagada por el marido legítimo, y caso de que el adúltero fuera insolvente, tanto a él, como a la mujer culpable se les colgaba por las muñecas de sendos árboles, de tal forma que sus pies quedaran suspendidos en el aire y completamente desnudos, siendo insultados y vejados y hasta apaleados por los vecinos hasta que el marido, compadecido de su estado, cortaba las cuerdas de las que colgaban los reos, quedando tendidos en el suelo, hechos verdaderos "ecce-homos".

En las tierras del sur de la isla, sin embargo las mujeres adúlteras eran colgadas desnudas de un árbol con los brazos en cruz, atados cada uno a una rama diferente, y los pies en el aire y de éstos solían colgarles calderos o cestos llenos de piedras, de tal forma que descoyuntaban sus miembros y producian terribles heridas en sus muñecas y así permanecían, escarnecidos por todo el poblado, generalmente hasta morir. Fue precisa toda la energía de las autoridades españolas para conseguir eliminar tan bárbaras costumbres, que aún se aplicaban hacia 1910 en algunos poblados de la isla.

42 Usera y Alarcón, Jerónimo M.: Memoria de la isla de Fernando Póo. Madrid, 1948, p. 13.

43 Sonela, Luis: Las posesiones españolas del golfo de Guinea: presente y futuro. 1884, pp. 8 y ss.

${ }_{44}$ AYMeni, Padre: Los bubis en Fernando Póo, publicado por Dirección general de Marruecos y colonias en 1942 . 


\section{Las penas en derecho consuetudinario pamúe ${ }^{45}$}

Concluimos refiriéndonos al nativo de la Guinea continental: EL PAMÚE.

En la costumbre del negro, está previsto todo: las penas a imponer a los que delinquen también y es el hechicero quien, tras consulta a las potencias invisibles, regula el castigo a imponer. Existe una amplia gama de penas, llegando incluso a la de muerte, pero solo en caso de brujería. Lo más frecuente es el señalamiento de un castigo tipificado en un rito expiatorio.

Además de esta transcendecia en el plano del mundo suprasensible, trasgredir la norma puede tener otras consecuencias: el resarcimiento del daño material ocasionado. Aquí, la intencionalidad del transgresor no significa nada. En realidad para el nativo no existe casualidad. Si el hecho se ha producido fortuitamente lo atribuirá a la intención maléfica de un ser misterioso. El pobre mortal que ha provocado su actuación será el responsable, únicamente si el daño se ha originado como consecuencia de la actuación de un brujo oculto quedará sin resarcirse el perjudicado.

La cuantía de las compensaciones son fijadas taxativamente en una tabla, ateniéndose en la tasación solamente al daño objetivo, sin que el elemento intencional influya, para nada, en la cuantía.

Si se tratara de daños materiales en las cosas, la sustitución por otra equivalente soluciona la cuestión. Si se trata de animales se resolverá análogamente.

Las lesiones corporales solían compensarse con la entrega de una cantidad variable de "bicuelas" ${ }^{46}$ o bien se pagaba en ganado. En la determinación influye notablemente la calidad de la persona lesionada.

También se compensa recíprocamente el daño mutuamente producido; si ha habido un muerto, la reparación consiste en la entrega de una mujer o más de una, si el muerto fuera de calidad.

De muy distinto signo eran las sanciones a las mujeres. A las adúlteras se les somete a castigos atroces. Aprisionándolas en un cepo junto a un hormiguero, aunque siempre se procedía a su liberación cuando las hormigas iniciaban su labor.

45 TRUJEDA INCERA, Luis: Los pamúes de nuestra Guinea (estudios de derecho consuetudinario). IDEA-CSIC. Madrid, 1947.

46 Equivalente a las monedas. 
Otro castigo frecuente era atarlas de espalda al suelo, desnudas y aplicarles sustancias irritantes en los genitales. Mientras la mujer se retorcia, se exponía a pública consideración, la falta por ella cometida, exhortando a las demás mujeres a tomar ejemplo. También estaba muy extendida la costumbre de sujetarla al suelo, boca abajo, hacerla cinco tajos en la espalda y mantenerla en ésta posición durante varios días. La otras faltas de las mujeres eran disculpables y los pequeños robos que solían cometer lo consideraban natural, limitándose a una paliza y un resarcimiento, por el marido, de los objetos robados.

Incluso a los niños se les sancionaba, siendo uno de los más frecuentes, la aplicación sobre los ojos de sustancias irritantes. Corregidas estas tendencias desde la infancia, era raro el hombre que cometía robos o faltas de alguna gravedad contra sus compañeros de grupo.

Hay un delito severamente castigado: el de hechicería sobre los miembros del grupo, birn, de forma directa (produccion de enfermedades, la muerte...) o bien de forma indirecta (actuando para impedir el éxito en una empresa).

Una vez localizado el brujo, su perdición es segura, sometido a un feroz y terrible castigo. Si la comunidad se limitase a dar muerte al brujo, su alma, desde la nueva situación actuaría vengadora, acaso con más ensañamiento que antes, contra los mortales del grupo. Por esto, es preciso someter al culpable a un suplicio adecuado. Un procedimiento de muerte que anule, a la vez, la vida posterior de cuerpo y alma. Para ello, hay que atender a una serie de requisitos que sólo los ancianos conocen. La ejecución se lleva a cabo en un día determinado, propicio, coincidente con ciertas fases lunares. El brujo, mientras tanto, permanece preso, desprovisto de vestiduras y de cuanto pudiera servirle para una actuación mágica. Recibe únicamente los escasos alimentos que le permitan subsistir hasta el día señalado.

El día de ejecucióm es un día de fiesta donde las autoridades son invitadas y los bailes desenfrenados desempeñan un papel fundamental.

No hay una norma general para la ejecución del reo. Si hubiera una cascada en las proximidades, sería un buen procedimiento arrojarle por ella. Así, el genio de la cascada se quedaría con él y no habría nada que temer. Otro método muy utilizado era atarlo junto a un hormiguero o ponerle inerme en el bosque a tiro de las fieras. Las hormigas, que en pocas horas no dejan ni el esqueleto, habrán ingerido junto al cuerpo mortal, el espíritu que lo animaba, y, disperso en numerosos insectos, no será peligroso, como tampoco lo será si se lo comen las fieras, aunque en este caso puede suceder la transmigración del alma del brujo al cuerpo del 
animal devorador, con el consiguiente peligro. Por ello, lo más general, es la cremación del culpable de brujería. La escena resulta así más ejemplarizadora. Sin ninguna duda, las feroces contorsiones de la víctima sobre el fuego purificador, mientras los cánticos aplastan rítmicamente sus alaridos, debían ser un espectáculo impresionante y aterrador. 